\title{
Overseas science shake-up in US
}

Malone goes,

Law of Sea

again in limbo

\section{Washington}

The US State Department is carrying out a shake-up of some of its top officials responsible for international scientific and technological affairs. Last week, the department confirmed that Mr James L. Buckley, a former Republican senator who is now Under-Secretary of State for Security Assistance, Science and Technology, will become a direct assistant to Secretary of State Alexander Haig.

Mr Buckley's move coincides with the news, also confirmed by the department, that Mr James Malone is being removed from his post as Assistant Secretary of State for Oceans and International Environmental and Scientific Affairs, although he will remain head of the US delegation to the Law of the Sea negotiations which reopened in New York last week.

No official reasons have been given for the reshuffle. In the case of Mr Malone, who was previously a lawyer in private practice and had been general counsel of the Arms Control and Disarmament Agency under the Nixon Administration, sources in Washington suggest that there had recently been criticism of some of his staff appointments. It is also felt that $\mathrm{Mr}$ Malone had lacked sufficient time to provide adequate attention to a range of controversial policy areas for which his post is responsible.

The moves are also part of a general reorganization of the State Department which has followed the promotion of Deputy Secretary of State William Clark to the President's National Security Advisor. One result is expected to be a more pragmatic and less ideological approach to decisions involving technology and foreign policy.

The contraction of Mr Malone's responsibilities seems, in part, to be related to his failure to secure congressional backing for the proposed relaxation of restrictions on the export of nuclear technology.

Mr Malone, whose nomination to the State Department was backed by members of the right wing of the Republican party, and who has contributed to reports published by the conservative Heritage Foundation, ran into strong opposition during his nomination hearings over his previous links with the nuclear industry.

At the time it was revealed that, as a private lawyer, he had represented the nuclear industries of both Taiwan and Japan in negotiations with the United
States over access to nuclear technology. He promised to distance himself from any policy decisions involving former clients, but his links with the industry raised questions about how far his efforts to reformulate the US position on nuclear non-proliferation reflected the views of the industry rather than the foreign policy interests of the nation as a whole.

Whether or not the charge was a fair one, it has limited the effectiveness with which Mr Malone has been able to argue the Administration's position. "Once his nomination had been approved, he did not help matters by producing position papers that clearly looked like industry documents," an aide to Senator John Glenn, one of the sharpest critics of $\mathrm{Mr}$ Reagan's efforts to boost the exports of the US nuclear industry, said last week.

Although no announcement has been

\section{European fusion sustained}

\section{Brussels}

Funds to be devoted to Europe's research effort in controlled thermonuclear fusion were increased from 900 to about 1,400 million European Currency Units (1 $E C U=£ 0.56)$ at a meeting of the EEC's science ministers in Brussels last week. JET, the Joint European Torus, which is being built at Culham in the United Kingdom will have a 319 million ECU budget for 1982-86 when the construction phase will be completed. European Community finance for other European fusion research has been set at $\mathbf{3 0 1}$ million ECU. This, with the contributions from national research budgets, will bring European fusion spending up to 1,400 million ECU over the next five years. The contribution from the EEC's budget for JET alone is thus increased from 195 to 319 million ECU.

In fact, most details of the fusion programme had been worked out well before the ministerial council; however, the British did their best to cut down support for general fusion research to $\mathbf{2 8 0}$ million ECU, a long way from the 325 million ECU originally requested by the European Commission, by arguing that the Commission had overestimated the speed of new developments. The European Commission calculated that 80 scientists would be needed to work on planning NET, the Next European Torus, and that accounted for much of the increased budget. But UK officials thought that because countries such as the United States or Japan were making do with 50 planners, the EEC could also do with fewer. The 301 million ECU finally agreed are supplemented by national contributions for projects involving tokamaks smaller than JET and other types of plasma confinement systems. The timetable for JET made about Mr Malone's successor, it is widely expected that several of his responsibilities for nuclear export policy will be transferred to $\mathbf{M r}$ Richard Kennedy, Under-Secretary of State for Management as well as ambassador to the International Atomic Energy Authority.

Mr Kennedy was a member of the Nuclear Regulatory Commission between 1976 and 1980 . Before that he served for five years on the staff of the National Security Council where he worked directly under Dr Henry Kissinger, and has therefore had wide experience of both nuclear and foreign policy.

Mr Malone's reassignment could also have an impact on the outcome of the Law of the Sea negotiations, where the United States is at the centre of two separate conflicts, on the one hand expressing its strong opposition to some of the provisions in the

foresees its tokamak in operation by the end of 1986.

At the press conference held by Philippe Maystadt, the Belgian science minister, who chaired the council, speculation was aroused by the omission of further international cooperation with the Soviet Union. Cooperation with Japan and the United States is to be strengthened during the new programme, he said. All four fusion "powers", are, however, cooperating with the International Atomic Energy Agency in Vienna on the Intor project, a post-JET tokamak, originally proposed by the Soviet Union. Cooperation among the Western powers is taking place simultaneously within the International Energy Agency in Paris and this may now be strengthened. The European Commission refutes the idea that an iron curtain is to be drawn across fusion research as a result of the present political tensions, since it is a field which has traditionally been kept outside EastWest politics.

The meeting also approved a research programme on raw materials for 54 million ECU which covers a wide variety of different research projects including research in metals and minerals, wood, the recycling of non-ferrous metals and ceramics.

The rest of the meeting was devoted to discussing two policy papers on the reorganisation of European research cooperation resulting from the meeting held last November. Among the ideas now being given serious consideration is the setting up of a Perception and Assessment Committee, which would bring together about twenty senior members to analyse the trends of science technology and guide EEC projects to counterbalance any deficiencies. 
current draft of a proposed international treaty, on the other not wishing to provoke a split with other industrialized nations which, although expressing reservations, are less inclined to reject the treaty as it now stands.

Last Thursday, the US delegation presented the conference with a list of changes that it says must be made before it will sign the treaty. These include the abandonment of efforts to place limits on the amounts of different minerals that can be retrieved from the sea bed, a revised voting procedure that would give the United States greater influence over the actions of an international authority established to regulate deep-sea mining, and dropping the requirement that US mining companies should provide Third World consortia with the latest mining equipment.

At the beginning of what is expected to be the final round of negotiations started in the early 1970s, several non-aligned countries indicated that it was too late to reopen discussion on topics which, they claimed, had been settled at earlier negotiating sessions. These countries said they would proceed with drawing up a treaty, leaving the United States to decide whether or not it wants to sign.

Behind the rhetoric, however, the real question is how far each side is prepared to compromise. A treaty without a US signature, or US financial support for the regulatory institutions which would be set up, would be of limited impact. From the American point of view, some prospective mining companies are concerned that they might be unable to raise credit from multinational banks if the treaty went ahead without a US signature, while several industrialized countries - including France, Britain and West Germany - are reluctant to jeopardize their trading relationships with Third World nations by providing too much support for the United States.

David Dickson

\section{Polish higher education}

\section{Reform reversed}

Research projects in Poland are now to be "rechecked" to assess their usefulness to the national economy, according to $\mathrm{Dr}$ Benon Miskiewicz, the new Minister of Science, Higher Education and Technology. Furthermore, the system for appointing assistant lecturers will be modified, and new principles worked out for the employment of graduates.

Dr Miskiewicz was addressing a meeting of lecturers from higher educational institutes subordinate to his ministry. The gathering did not include medical schools or specialist bodies such as the Mining and Metallurgy Institute of Krakow which, last September, had been a principal focus of resistance to attempts by the then minister, Mr Jerzy Nawrocki, to renege on the academic autonomy which, it had been promised, would be incorporated into the new higher education bill. This bill, much delayed by the imposition of martial law, is now apparently undergoing redrafting and modification before going forward to the Sejm (parliament).

Dr Miskiewicz's emphasis on the "usefulness" of research suggests a reemphasis of the "problem-orientated" research structure introduced in 1973 by which all research had to be associated with a specific problem of the national economy. This led to an unseemly scramble by researchers to find a "problem" rated as highly as possible by the planners. During the open press debates last summer on the future of Polish science, it was generally admitted that the "problem" structure had failed and should be replaced by some type of direct contact with industry.

By tacitly repudiating such proposals, Dr Miskiewicz was apparently trying to dissociate his ministry from such proposed reforms. During the past three months, there has been some high-level disagreement as to who was primarily responsible for the outspokenness of the academic community - the Academy of Sciences or the universities. Talking to the editorial board of the weekly magazine Polityka last January, Deputy Premier Mieczyslaw Rakowski said that the breaking point had come when the Conference of University Rectors had demanded a voice in the appointment of the Minister of Science, Higher Education and Technology. The conference, established in September 1980, was always regarded with suspicion by the government, and shortly after the declaration of martial law it was dissolved - unlike the majority of organizations which were simply suspended.

Officials of the Ministry of Science, Higher Education and Technology, however, blame the Academy of Sciences, whose institutes, they say, harboured dissidents who had been banned from university teaching. The proposed new law on the academy, which would have made the academic secretary responsible only to his fellow members and not, as at present, to the prime minister, has been abandoned. The limited autonomy which the academy has until exercised over its research budget, is likely to be reduced even further.

The authorities, however, seem unwilling to risk any further direct confrontation with the academy. A recent meeting of the presidium of the academy was addressed by Dr Hieronim Kubiak, the Communist Party spokesman on higher education, who is reputed to be the most liberal member of the Politburo. Dr Kubiak warned the academicians against pointless confrontation, stressing that the intelligentsia should "advocate a Poland which is possible"'. Nevertheless, he said, if there are reforms which are actually possible at present, one should support them openly and actively. Vera Rich

\section{Industrial lure}

\section{New York}

As five university presidents prepare to discuss the growing connection between universities and commercial interests in recombinant DNA research (Nature 4 March, p.1), private biotechnology firms continue to have an increasing impact. This week, two top academics decided to give up basic research posts to join private companies.

Dr Walter Gilbert, 1980 Nobel prize winner in chemistry, is to leave his American Cancer Society professorship at Harvard University as of June to retain his position as executive officer of Biogen, the Geneva- and now Cambridge-based biotechnology firm.

Dr Gilbert has had a two-year leave of absence from Harvard to fulfil his position as chairman of the board of directors of Biogen. His hopes of permanently maintaining both his laboratory at Harvard and his position at Biogen ran into unresolvable problems with the Harvard administration. He will, however, remain a senior associate of the university for two more years. His Harvard laboratory will continue to operate during this time.

His full-time commitment to Biogen comes at a time when the company's new American laboratory in Cambridge, Massachusetts has recently adopted another academic, Dr Richard Flavell from the National Institute of Medical Research at Mill Hill, as research director. Dr Flavell is officially on two-year leave of absence from Mill Hill.

Another top American academic to move into the private sector, Dr Edward Scolnick, chief of the laboratory of tumour virus genetics at the National Cancer Institute, has decided to become Merck, Sharpe and Dohme's executive director of virus and cell biology.

Michael Stein

\section{UK budget

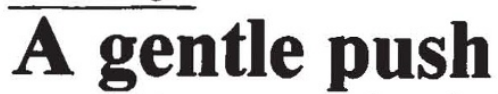

The British government's enthusiasm for new technologies, and its lack of enthusiams for the universities, was confirmed in last week's budget. While the universities can expect little respite from the austerity promised a year ago, the development of new technologies in industry is to receive a modest boost. British Telecom, which is to be allowed to increase its annual capital expenditure by a half over the next three years, is the chief beneficiary. But the Chancellor of the Exchequer has also promised the Department of Industry an extra $£ 130$ million for new technology in the next financial year, 1982-83. 